\title{
Editorial
}

\section{The Dark Side of the Long-Term Use of Proton Pump Inhibitors in Chronic Liver Disease}

\author{
Samuel Raimundo Fernandes Rui Tato Marinho \\ Serviço de Gastrenterologia e Hepatologia, Hospital de Santa Maria, Centro Hospitalar Lisboa Norte, \\ Lisbon, Portugal
}

\section{Keywords}

Proton pump inhibitors · Dyspepsia - Cirrhosis .

Spontaneous bacterial peritonitis

O ladro negro da utilização crónica de inibidores da bomba de protões na doença hepática crónica

\section{Palavras Chave}

Inibidores da bomba de protões · Dispepsia - Cirrose .

Peritonite bacteriana espontânea

Proton pump inhibitors (PPIs) are among the most widely prescribed drugs in the world today. Accepted indications include an array of acid-related disorders such as peptic ulcer disease and gastroesophageal reflux, and the prevention of non-steroid anti-inflammatory drug (NSAID)-induced ulcers. Despite little evidence of efficacy, PPIs are also frequently prescribed for other indications including functional dyspepsia and for the prevention of gastroduodenal side effects of polypharmacy. Alarmingly, up to two-thirds of PPI prescriptions in ambulatory patients may be inadequate [1-3].

In recent years, several observational studies have raised concern regarding the potential long-term side ef-

\section{KARGER}

E-Mail karger@karger.com www.karger.com/pjg
(C) 2018 Sociedade Portuguesa de Gastrenterologia Published by S. Karger AG, Basel

Karger

Open access

This article is licensed under the Creative Commons AttributionNonCommercial-NoDerivatives 4.0 International License (CC BYNC-ND) (http://www.karger.com/Services/OpenAccessLicense) Usage and distribution for commercial purposes as well as any distribution of modified material requires written permission. fects of PPIs, including acute and chronic kidney disease, hypomagnesemia, cardiovascular events, bone fractures, dementia, and infections such as Clostridium difficile colitis, bacterial pneumonia, and spontaneous bacterial peritonitis (SBP) $[4,5]$. SBP is a well-known complication in patients with cirrhosis and ascites. Despite improvements in medical care with timely diagnosis and treatment with antibiotics, short-term mortality of SBP amounts to about $30 \%$ and increases to over $65 \%$ at 1 year without liver transplantation [6]. Therefore, means of reducing the rates of SBP in patients with cirrhosis are welcomed.

SBP is thought to result from bacterial translocation across the intestinal wall leading to infection of the ascitic fluid. Proliferation of bacteria in the ascitic fluid is favored in patients with cirrhosis by a dysfunctional immune system with low levels of immunoglobulins, opsonizing proteins, and complement [7]. Hypothetically, by increasing intragastric $\mathrm{pH}$, PPIs facilitate proliferation of intestinal bacteria (i.e., bacterial overgrowth). Abnormal gastrointestinal motility is also common in patients with cirrhosis and may further be worsened by PPIs [8, 9]. Even more preoccupying is the fact that over $63 \%$ of prescriptions of PPIs in patients with cirrhosis may be inadequate [10]. At a time of growing concern over rising health care costs, substantial cost savings can be achieved by limiting inappropriate prescribing of PPIs according to the clinical guidelines [11]. 
In the current issue of the Portuguese Journal of Gastroenterology, Elzouki et al. [12] once again tackle the controversial issue of PPIs and infections, including SBP in patients with decompensated cirrhosis. They include 333 patients, most with alcohol and viral cirrhosis. It is noteworthy that the majority of patients were using PPIs (51.4\%) and over $43 \%$ had no formal indication. The authors show a significant higher incidence of overall bacterial infections (38 vs. $13.6 \%, p=0.0001$ ) including SBP (25.7 vs. $10.5 \%, p=0.0006)$ in patients using PPIs. However, it should be noted that PPI users were older and suffered from more comorbidities (diabetes mellitus, hypertension, and chronic liver disease, although the later not significant), all potentially confounders known to be associated with an increased risk of infections [13]. Two recent meta-analyses, including mostly observational studies, have reached the same conclusions $[14,15]$. PPIs were associated with an increased risk of overall bacterial infection $(\mathrm{OR}=1.98,95 \% \mathrm{CI} 1.36-2.87)$ and SBP $(\mathrm{OR}=$ $2.11,95 \%$ CI $1.46-3.06$ and $\mathrm{OR}=2.17,95 \%$ CI $1.46-3.23$ ).

However, as pointed out by most studies, correlation does not imply causation. Furthermore, even if the risk of overall infections may be higher, there does not appear to be a signal for increased mortality associated with PPI use.
Currently, it remains unclear as to whether PPIs should be stopped in every patient with advanced cirrhosis and whether this translates in improved outcomes. Acid-related disorders are common in patients with liver cirrhosis [16]. Advanced age, Helicobacter pylori, and chronic intake of NSAIDs are known to play a key role in most cases of peptic ulcer disease. However, this may not always be the case in patients with cirrhosis where idiopathic ulcers appear to be more common and may be related to the chronic consumption of alcohol and portal hypertension [17]. Furthermore, evidence suggests that patients with liver cirrhosis and non-variceal gastrointestinal bleeding may have inferior outcomes than non-cirrhotic patients [16].

In conclusion, while mounting evidence suggests that PPIs are not as benign as previously thought, clearly, we should focus on improving the selection of patients who will gain a substantial clinical benefit from long-term PPI therapy. More high-quality prospective studies are needed in this area.

\section{Disclosure Statement}

The authors have no conflicts of interest to declare.

\section{References}

1 Mat Saad AZ, Collins N, Lobo MM, O'Connor HJ: Proton pump inhibitors: a survey of prescribing in an Irish general hospital. Int J Clin Pract 2005;59:31-34.

2 Ahrens D, Chenot JF, Behrens G, Grimmsmann T, Kochen MM: Appropriateness of treatment recommendations for PPI in hospital discharge letters. Eur J Clin Pharmacol 2010;66:1265-1271.

3 Targownik L: Discontinuing long-term PPI therapy: why, with whom, and how? Am J Gastroenterol 2018;113:519-528.

4 Xavier S, Magalhães J, Cotter J: Proton pump inhibitors: are they a real threat to the patient? GE Port J Gastroenterol 2018, DOI: 10.1159/ 000487154.

5 Schoenfeld AJ, Grady D: Adverse effects associated with proton pump inhibitors. JAMA Intern Med 2016;176:172-174

6 Lim KH, Potts JR, Chetwood J, Goubet S, Verma S: Long-term outcomes after hospitalization with spontaneous bacterial peritonitis. J Dig Dis 2015;16:228-240.

7 Ono Y, Watanabe T, Matsumoto K, Ito T, Kunii O, Goldstein E: Opsonophagocytic dysfunction in patients with liver cirrhosis and low responses to tumor necrosis factor-alpha and lipopolysaccharide in patients' blood. J Infect Chemother 2004;10:200-207.
8 Pande C, Kumar A, Sarin SK: Small-intestinal bacterial overgrowth in cirrhosis is related to the severity of liver disease. Aliment Pharmacol Ther 2009;29:1273-1281.

9 Parkman HP, Urbain JL, Knight LC, et al: Effect of gastric acid suppressants on human gastric motility. Gut 1998;42:243-250.

10 Kalaitzakis E, Björnsson E: Inadequate use of proton-pump inhibitors in patients with liver cirrhosis. Eur J Gastroenterol Hepatol 2008; 20:512-518

11 Cahir C, Fahey T, Tilson L, Teljeur C, Bennett K: Proton pump inhibitors: potential cost reductions by applying prescribing guidelines. BMC Health Services Research 2012;12:408.

12 Elzouki A, Neffati N, Rasoul F, Abdallah A, Othman M, Waness A: Increased risk of Spontaneous bacterial peritonitis in cirrhotic patients using proton pump inhibitors. GE Port J Gastroenterol 2018, in press.

13 Elkrief L, Rautou PE, Sarin S, Valla D, Paradis V, Moreau R: Diabetes mellitus in patients with cirrhosis: clinical implications and management. Liver Int 2016;36:936-948.
14 Yu T, Tang Y, Jiang L, Zheng Y, Xiong W, Lin L: Proton pump inhibitor therapy and its association with spontaneous bacterial peritonitis incidence and mortality: a meta-analysis. Dig Liver Dis 2016;48:353-359.

$15 \mathrm{Xu} \mathrm{HB}$, Wang HD, Li CH, Ye S, Dong MS, Xia QJ, Zhang AQ, Pan K, Ge XL, Dong JH: Proton pump inhibitor use and risk of spontaneous bacterial peritonitis in cirrhotic patients: a systematic review and meta-analysis. Genet Mol Res 2015;14:7490-7501.

16 Gonzalez-Gonzalez JA, Garcia-Compean D, Vazquez-Elizondo G, Garza-Galindo A, Jaquez-Quintana JO, Maldonado-Garza H: Nonvariceal upper gastrointestinal bleeding in patients with liver cirrhosis. Clinical features, outcomes and predictors of in-hospital mortality. A prospective study. Ann Hepatol 2011;10:287-295.

17 Rudler M, Rousseau G, Benosman H, Massard J, Deforges L, Lebray P, Poynard T, Thabut D: Peptic ulcer bleeding in patients with or without cirrhosis: different diseases but the same prognosis? Aliment Pharmacol Ther 2012;36:166-172. 